\title{
Can future systemic financial risks be quantified? Ergodic vs nonergodic stochastic processes
}

\author{
PAUL DAVIDSON*
}

Different axioms underlie efficient market theory and Keynes's liquidity preference theory. Efficient market theory assumes the ergodic axiom. Consequently, today's decision makers can calculate with actuarial precision the future value of all possible outcomes resulting from today's decisions. Since in an efficient market world decision makers "know" their intertemporal budget constraints, decision makers never default on a loan, i.e., systemic defaults, insolvencies, and bankruptcies are impossible. Keynes liquidity preference theory rejects the ergodic axiom. The future is ontologically uncertain. Accordingly systemic defaults and insolvencies can occur but can never be predicted in advance.

Keywords: ergodic axiom; efficient market theory; liquidity preference theory; probabilistic risk; uncertainty.

JEL Classification: G1; D80; E1.

Politicians and talking heads on television are continuously warning the public that the current economic crisis that began in 2007 as a small sub prime mortgage default problem in the United States has created the greatest economic catastrophe since the Great Depression. What is rarely noted, however, is that what is significant about this current economic crisis is that it origin, like the origin of the Great Depression, lies in the operations of free (deregulated) financial markets. As I pointed out in two recent articles (Davidson, 2008a, 2008b), it is the deregulation of the financial system that began in the 1970s in the United States that is the basic cause of our current financial market distress.

Yet for more than three decades, mainstream academic economists, policy

\footnotetext{
* Bernard Schwartz Center for Economic Policy Analysis, The New School, New York. E-mail: pdavidson@utk.edu. This article appeared on RGEmonitor.com — Global Macro Economic Monitor, April 7, 2009. The argument and its policy implication, both domestically and internationally, are developed in my forthcoming book The Keynes Solution, Palgrave/Macmillan, Summer 2009.
} 
makers in government and Central Bankers and their economic advisors insisted that (1) both government regulations of markets and large government spending policies are the cause our economic problems and (2) ending big government and freeing markets from government regulatory controls is the solution to our economic problems.

In an amazing "mea culpa" testimony before Congress on October 23, 2008, Alan Greenspan admitted that he had overestimated the ability of free financial markets to self-correct and he had entirely missed the possibility that deregulation could unleash such a destructive force on the economy. Greenspan stated:

"This crisis, however, has turned out to be much broader than anything I could have imagined [...] those of us who had looked to the self interest of lending institutions to protect shareholder's equity (myself especially) are in a state of shocked disbelief [...] In recent decades, a vast risk management and pricing system has evolved, combining the best insights of mathematicians and finance experts supported by major advances in computer and communications technology. A Nobel Prize [in economics] was awarded for the discovery of the [free market] pricing model that underpins much of the advance in [financial] derivatives markets. This modern risk management paradigm held sway for decades. The whole intellectual edifice, however, [has] collapsed.”

Under questioning by members of the Congressional committee Greenspan admitted: "I found a flaw in the model that I perceive is the critical functioning structure that defines how the world works. That's precisely the reason I was shocked [...] I still do not fully understand why it happened, and obviously to the extent that I figure it happened and why, I shall change my views".

The purpose of this paper is to explain the fundamental problem confronting anyone attempting to quantify systemic financial risks regarding future outcomes in a money using capitalist economy.

\section{THEORIES EXPLAINING THE OPERATION OF A CAPITALIST ECONOMY}

There are two fundamentally economic theories that attempt to explain the operation of a capitalist economy and its financial markets. These are:

(1) the classical economic theory which has many variants such as "the theory of efficient markets", "classical or neoclassical theory", "general equilibrium theory", "dynamic general equilibrium theory" or "mainstream economic theory". The mantra of this analytical system is that free markets can cure any economic problem that may arise, while government interference always causes economic problems. In other words, government economic policy is the problem, the free market is the solution.

(2) the Keynes liquidity theory of an entrepreneurial economy. The conclusions 
of this analysis is that government can cure, with cooperation of private industry and households, economic flaws inherent in the operation of a capitalist economy especially when unfettered greed or fear is permitted to dominate economic decisions.

Time is a device for preventing everything from happening at once. Economic decisions made today will have outcomes that can only be evaluated days, months or even years in the future. The basic - but not only - difference between these two alternative theories that explain the operations of a capitalist economy is how each theory treat knowledge about future outcomes that decision makers have when making today's decisions. In essence, the classical efficient market theory presumes that by one method or another decision makers today do, or at least can, obtain reliable quantitative knowledge about the risks regarding future outcomes of any decision made today. Given this quantitative knowledge regarding future outcomes, the only economic decision that today's market participants have to solve is the allocation of today's resources to produce the most valuable quantitative outcomes today and all future dates.

The Keynes liquidity theory on the other hand, presumes that decision makers "know" that they do not, and can not, know the future outcome of certain crucial economic decisions made today. Thus the Keynes theory explains how the capitalist economic system creates institutions that permit decision makers to deal with an uncertain future while making allocative decisions and then sleep at night. The Keynes theory would suggest that instead of attempting to quantify the unquantifiable systemic future risks, that society develop institutions that stabilize and make financial markets more orderly.

\section{READING TEA LEAVES: THE CLASSICAL SOLUTION FOR KNOWING THE FUTURE}

Advocates of classical economics believe that free markets are efficient. In a classical efficient market it is presumed that there are large numbers of rational decision makers who, before making a purchase or sales decision, collect and analyze reliable information on both the probability of events that have already occurred and on the probability of events that will occur in the future.

In previous centuries, economists such as Adam Smith, Ricardo, etc. merely assumed that today's market participants possessed complete information about the future and therefore, in a free market, rational participants will always evaluate the future benefit vs. current costs to make optimal decisions that represented their own best interests. To some an assumption that the future is already known may seem preposterous. Nevertheless this idea underlies the Greenspan belief (cited above) that the self interest of lending institutions in a free market should lead management to undertake transactions that protect shareholder's equity.

The classical theory presumption that the future is known or at least knowable is the foundation all of today's efficient market theories. For example, the mathematically sophisticated Arrow-Debreu general equilibrium model is the basic ana- 
lytical framework upon which most mathematical computer economic models used by economists are based. The Arrow-Debreu presumption is that markets exist today to permit participants to buy and sell all the products and services that will be delivered today and at every date in the future. Thus at the initial instant of time, it is presumed that all market participants enter into transactions for the purchases and sales of all products and services not only for delivery today but for delivery for all future dates till the end of time. In its extreme conceptualization, this complex mathematical model implies that buyers today not only know what goods and services they are going to demand in the market today, tomorrow and every future date for the rest of their lives, but today they also "know" what their grandchildren, great grandchildren, etc. will want to buy and sell decades and centuries from today. If efficient markets existed when Adam and Eve were banished from the Garden of Eden, then Adam and Eve, being ancestors to all of us alive today, would have made already entered into a future order to purchase whatever the reader is going to have for dinner tonight. Only the high level of mathematics and abstraction of this classical theory can bury its impossible axiomatic foundation.

Some of today's mainstream classical economists recognize that Arrow-Debreu's complete markets paradigm for every conceivable good and service for every future date till the end of time is impossible. For example in the financial times blog FT.com Willem Buiter is quoted (on 3/3/2009) as stating:

"The most influential New Classical and New Keynesian theorists all worked in what economists call a 'complete markets paradigm'. In a world where there are markets for contingent claims trading that span all possible states of nature (all possible contingencies and outcomes), and in which intertemporal budget constraints are always satisfied by assumption, default, bankruptcy and insolvency are impossible. As a result, illiquidity — both funding illiquidity and market illiquidity — are also impossible, unless the guilt-ridden economic theorist imposes some unnatural (given the structure of the models he is working with), arbitrary friction(s), that made something called 'money' more liquid than everything else, but for no good reason. The irony of modeling liquidity by imposing money as a constraint on trade was lost on the profession.

Both the New Classical and New Keynesian complete markets macroeconomic theories not only did not allow questions about insolvency and illiquidity to be answered. They did not allow such questions to be asked [...] Beyond this simple 'impossibility of complete markets' proposition, there is the deeper point, that the assumption of complete markets in most of the New Classical and New Keynesian macroeconomics assumes away the problem of contract enforcement. This problem is especially acute in trade over time or intertemporal trade, where the net value to each party to a contract of fulfilling the terms of the contract varies over time and can change sign.” 
Nevertheless most mainstream economists still believe in the efficiency of free markets and the ability of decision makers to correctly quantify future systemic financial risks of today's portfolio decisions. To salvage their efficient market conclusions in the absence of a complete markets paradigm, most economists assume that market participants possess "rational expectations" regarding all future possible outcomes of any decision made today. Lucas's theory of rational expectations asserts that although individuals presumably make decisions based on their subjective probability distributions, nevertheless if expectations are to be rational these subjective distributions must be equal to the objective probability distributions that will govern all possible outcomes at any particular future date. In other words, somehow today's rational market participants possess statistically reliable information regarding the probability distribution of the universe of future events that will occur on any specific future date.

\section{WHAT IS REQUIRED TO QUANTIFY FUTURE SYSTEMIC FINANCIAL RISKS?}

To obtain a reliable probability distribution about a future financial markets universe, the market participant analyst should draw a random sample from that future universe. Then the analyst can analyze this sample from the future to calculate statistically reliable information about the mean, standard deviation, etc. of this future population. Thus, the analyst can reduce uncertainty about prospective outcomes to a future of actuarial certainties expressed as objective probabilistic risks.

Since drawing a sample from the future is not possible, efficient market theorists must presume that probabilities calculated from already existing market data is equivalent to drawing a sample from the market universe that will exist in the future. This presumption is known as the ergodic axiom which, in essence, presumes that the future is merely the statistical shadow of the past. Only if this ergodic axiom is accepted as a universal truth, will calculating probability distributions (risks) on the basis of historical market data be statistically equivalent to drawing and analyzing samples from the future. Only under the ergodic axiom is the past and the future all rolled up into one!

Those who claim that economics is a "hard science" like physics or astronomy argue that the ergodic assumption must be the foundation of the economists' model. In 1969, for example, Nobel prize economist Paul Samuelson (1969), who is often thought to be the originator of post second world war "Keynesianism", wrote that if economists hope to remove economics from the realm of history and move it into the "realm of science" we must impose what Samuelson called the "ergodic hypothesis".

An axiom is defined as a universal truth that needs not be proved. The classical ergodic axiom permits economists to claim that probabilities calculated from past and current market data provide reliable actuarial knowledge about the future. In other words, the future is merely probabilistically risky but not uncertain.

The assumption that the economy is governed by an ergodic stochastic process 
means that the future path of the economy is already predetermined and can not be changed by human action today. Astronomers insist that the future path of the planets around the sun and the moon around the earth has been predetermined since the moment of the Big Bang beginning of the universe. Nothing humans can do can change the predetermined path of these heavenly bodies. This "Big Bang" astronomy theory means that the "hard science" of astronomy relies on the ergodic axiom. Consequently by using past measurements of the speed and direction of heavenly bodies, astronomical scientists can accurately predict the time (usually within seconds) of when the next solar eclipse will be observable on the earth.

Assuming that this hard science astronomy is applicable to the heavenly bodies of our universe, then it should be obvious that the United States Congress can not pass legislation that will actually prevent future solar eclipses from occurring even if the legislation is designed to obtain more sunshine to improve agriculture crop production. In a similar vein, if, as Samuelson claims, economics is a "hard science" based on the ergodic axiom, then Congress can neither pass a law preventing the next eclipse nor pass a law to prevent the preprogrammed next systemic financial crisis. The result is a belief in a laissez-faire non government intervention policy as the only correct policy.

Logically consistent efficient market analyses suggest that active government economic policies that interfere with free markets create an "external shock" to the system. By an "external shock" the efficient theory economists mean that government policy is equivalent to throwing something into the predetermined path of the economy pushing it temporarily off its path into a path involving more unemployment, resource waste, etc.

If markets were efficient and not constrained by onerous permanent government regulation and interference, then the action of participants in these efficient markets to any external shock caused by government policies will move the economy back to its predetermined efficient path, just as the law of gravity would restore the pendulum swing after the external shock of being hit by a pebble. In other words, whenever government policies shock the economic system, action by rational market participants in a free market, in some unspecified time (i.e., the long run), will restore the system back to its predetermined efficient path (by purging "the rottenness out of the system" (as Treasury Secretary Andrew Mellon continually told President Hoover, according to Hoover's autobiography).

The highly complex computer models used by investment bankers in Wall Street in recent years to evaluate and manage the risks of dealings with financial assets is based on statistical probability analysis of historical data to predict the future. Given the necessity of the government, in 2008, to bail out all these Wall Street investment bankers when their risk management tools failed, it should be obvious that their risk management computer models presumed the ergodic axiom while the real world environment was nonergodic. That is why all these risk management models failed to predict the 2008 future.

The Oxford mathematician Jerome Ravitz in an article entitled "Faith and 
Reason in The Mathematics of the Credit Crunch" appearing in Oxford Magazine (eighth week, Michaelmas term, 2008) has written:

"[...] the term faith is believed by these competent present observers to be relevant to the mathematics at the heart of the multi dimensional pyramid game that has led to our present [credit crunch] catastrophe. Combined with the corruption of quality and the abuse of uncertainty in mathematical models, blind faith in [classical] economics and mathematics forms $[\ldots]$ the toxic mix that has enabled greed an irresponsibility to wreak their destructive way. [...] Mathematics first provided an enabling technology with computers, then with a plausible theorem it offered legitimation for runaway speculation [...] it framed the quantitative specification of its fantasised products. Mathematics thereby became uniquely toxic, what Warren Buffet has called 'weapons of mass destruction'”.

\section{CLASSICAL THEORISTS VS., KEYNES ON THE REALITY OF ASSUMPTIONS}

If Keynes was alive today I think he might have called this theory of efficient markets a case of "weapons of math destruction". Yet, Robert Lucas (1981, p. 287) has boosted that the axioms underlying classical economics are "artificial, abstract, patently unreal". But like Samuelson, Lucas insists such unreal assumptions are the only scientific method of doing economics. Lucas insists that "Progress in economic thinking means getting better and better abstract, analogue models, not better verbal observations about the real world" (Lucas, 1981, p. 276). The rationale underlying this argument is that these unrealistic assumptions make the problem more tractable and, with the aid of a computer, the analyst can then predict the future. Never mind that the prediction might be disastrously wrong.

Computer based mathematical versions of classical efficient market theory involving thousands of variables and an equation for each variable have been put forth as a hard science description of our economic system that, at an point of time, simultaneously determines the price and output of every item that is traded in the economic system. For many even identifying the fundamental axioms buried under all the mathematical debris is an impossible task. Moreover, the fact that computers can manipulate all that mathematics gives the results an aura of scientific truth. How can a computer print-out be wrong?

In a 2009 article entitled "Probably Wrong - Misapplications of Probability and Statistics in Real Life Uncertainty", Oxford University's Peter Taylor and David Shipley of MAP Underwriting Agencies, Lloyd's of London suggests why all these computer print-out are wrong. Taylor and Shipley have written:

"There are lies, damned lies, and statistics [...] Probability and Statistics just don't feel right for many problems [...] They give the impres- 
sion of allowing fairly for the eventualities [...] and then something unexpected happens. [...] Those of a more pragmatic nature would want some measure of credibility such as the extent of applicability to a theory or a problem. In complex systems, the predictability that is so successful in the controlled worlds of the lab and engineering has not worked and yet theories claiming predictability have misled policy makers and continue to do so [...] We may even have to own up to not having an appropriate model at all, surely a modern-day heresy.”

Taylor and Shipley argue that we should learn from th current economic and financial crisis that:

"As investors, never trust a manager who says he has a superior mathematical model [...] As mangers leave room in your business model for the unexpected [...] As regulators focus on management's ability to understand real risk exposure, rather than the comfort blanket of a model [...] [and] As modelers, encourage critical awareness that the model may not represent all the relevant mechanisms for the process under consideration.”

In the introduction to his book Against The Gods, a treatise that deals with the questions of relevance of risk management techniques on Wall Street, Peter L. Bernstein $(1996$, p. 6) writes:

"The story that I have to tell is marked all the way through by a persistent tension between those who assert that the best decisions are based on quantification and numbers, determined by the [statistical] patterns of the past, and those who based their decisions on a more subjective degree of belief about the uncertain future. This is a controversy that has never been resolved."

One would hope that the empirical evidence of the collapse of those "masters of the economic universe " that have dominate Wall Street machinations for the last three decades has at least created doubt regarding the applicability of classical ergodic theory to our economic world.

\section{KEYNES'S LIQUIDITY THEORY FOR DEALING WITH THE UNCERTAIN FUTURE}

John Maynard Keynes's ideas support Bernstein's latter group. Keynes specifically argued that the uncertainty of the economic future can not be resolved by looking at statistical patterns of the past. Keynes's believed that today's economic decisions regarding spending and saving depend on individuals' subjective degree of belief regarding possible future events.

Keynes stated that classical economists 
"resemble Euclidean Geometers in a non-Euclidean world who, discovering that in experience straight lines apparently parallel often meet, rebuke the lines for not keeping straight - as the only remedy for the unfortunate collisions which are occurring. Yet in truth there is no remedy except to throw over the axiom of parallels and to work out a non-Euclidean geometry. Something similar is required today in economics."

To create a non-Euclidean economics to explain why these unemployment "collisions" occur in the world of experience Keynes had to deny ("throw over") the relevance of several classical axioms for understanding the real world. The classical ergodic axiom which assumes that the future is known and can be calculated as the statistical shadow of the past was one of the most important classical assertions that Keynes rejected. Instead Keynes argued that when crucial economic decisions had to be made, decision makers could not merely assume that the future can be reduced to quantifiable risks calculated from already existing market data.

Although in his discussion of uncertainty Keynes did not know or use the dichotomy between an ergodic and nonergodic stochastic system in his criticism of Tinbergen's methodology Keynes notes that economic time series can not be stationary because "the economic environment is not homogeneous over a period of time". Nonstationarity is a sufficient but not a necessary condition for a nonergodic stochastic process. Accordingly, Keynes was implicitly arguing that economic processes over time occur in a nonergodic economic environment.

\section{TAMING UNCERTAINTY IN KEYNES'S LIQUIDITY THEORY}

For decisions that involved potential large spending outflows or possible large income inflows that span a significant length of time, people "know" that they do not know what the future will be. Nevertheless, society has attempted to create institutions that will provide people with some control over their uncertain economic destinies.

In capitalist economies the use of money and legally binding money contracts to organize production and sales of goods and services permits individuals to have some control over their cash inflows and outflows and therefore some control of their monetary economic future. Purchase contracts provide household decision makers with some monetary cost control over major aspects of their cost of living today and for months and perhaps years to come. Sales contracts provide business firms with the legal promise of current and future cash inflows sufficient to meet the business firms' costs of production and generate a profit.

People and business firms willingly enter into contracts because each party thinks it is in their best interest to fulfil the terms of the contractual agreement. If, because of some unforeseen event, either party to a contract finds itself unable or unwilling to meet its contractual commitments, then the judicial branch of the government will enforce the contract and require the defaulting party to either meet 
its contractual obligations or pay a sum of money sufficient to reimburse the other party for all monetary damages and losses incurred. Thus, as the biographer of Keynes, Lord Robert Skidelsky has noted, for Keynes "injustice is a matter of uncertainty, justice a matter of contractual predictability".

In other words, by entering into contractual arrangements people assure themselves a measure of predictability in terms of their contractual cash inflows and outflows, even in a world of economic uncertainty.

In their book, Arrow and Hahn (1971, pp. 256-257 emphasis added) wrote "The terms in which contracts are made matter. In particular, if money is the goods in terms of which contracts are made, then the prices of goods in terms of money are of special significance. This is not the case if we consider an economy without a past or future [...] if a serious monetary theory comes to be written, the fact that contracts are made in terms of money will be of considerable importance". Only Keynes's liquidity theory explaining the operation of a capitalist economy provides this serious monetary theory as a way of coping with an uncertain future.

Money is that thing that government decides will settle all legal contractual obligations. This definition of money is much wider than the definition of legal tender which is "This note is legal tender for all debts, private and public".

An individual is said to be liquid if he/she can meet all contractual obligations as they come due. For business firms and households the maintenance of one's liquid status is of prime importance if bankruptcy is to be avoided. In our world, bankruptcy is the economic equivalent of a walk to the gallows. Maintaining one's liquidity permits a person or business firm to avoid the gallows of bankruptcy.

Since the future is uncertain, we never know when we might be suddenly faced with a payment obligation at a future date that we did not, and could not, anticipate, and which we could not meet out of the cash inflows expected at that future date. Or else we might suddenly find an expected cash inflow disappears for an unexpected reason. Accordingly we have a precautionary liquidity motive for maintaining a positive bank balance plus further enhancing our liquidity position to cushion the blow of any unanticipated events that may occur in the uncertain future.

If individuals suddenly believe the future is more uncertain than it was yesterday, then it will be only human to try to reduce cash outflow payments for goods and services today in order to increase our liquidity position to handle any uncertain adverse future events since our fear of the future has increased. The most obvious way of reducing cash outflow is to spend less income on produced goods and services - that is to save more out of current income.

This need for check book balancing and desire for an additional liquidity cushion is an irrelevant concept for the people who inhabit the artificial world of classical economic theory where the future is risky but reliably predictable. As we have already noted the complete markets paradigm of classical theory ensures that no one in this mythical world would ever enter into a contractual payment obligation they could not meet since every person would know their future net income and spending pattern today and at every date in the future. If some participant do 
enter into wrong contracts, they are permitted to recontract without any income penalty - a solution that is not permitted in our world of experience.

Efficient markets would never permit people to spend an amount that so exceeds their income that the debt can not be serviced. Markets would not be efficient, if people today enter into contractual transactions that they can not fulfil when the future occurs. Wouldn't credit card holders who are having trouble meeting even their monthly minimum credit card payment obligations and those mortgage borrowers who were foreclosed out of their homes be happy to know if only they had lived in the classical world of efficient markets, they would never have become entrapped in such burdensome contractual arrangements?

In a Keynes analysis, on the other hand, the civil law of contracts and the importance of maintaining liquidity play crucial roles in understanding the operations of a capitalist economy - both from a domestic national standpoint and in the context of a globalized economy where each nation may employ a different currency and even different civil laws of contracts. I can not pursue, in this paper, the international aspect of money and contracts, but I do discuss it in my book (Davidson, 2007) and my forthcoming book (Davidson, 2009).

In Keynes's theory the sanctity of money contracts is the essence of the entrepreneurial system we call capitalism. Since money is that thing that can always discharge a contractual obligation under the civil law of contracts, money is the most liquid of all assets. Nevertheless other liquid assets exist that have some lower degree of liquidity than money since these other assets cannot be "tended" i.e., handed to the party, to discharge a contractual obligation. As long as these other assets can be readily resold for money (liquidated) in a well organized and orderly financial market, however, they will possess a degree of liquidity. A rapid sale of the liquid asset for money will permit people to use the money received from the sale of financial assets to meet their contractual obligations.

By an orderly market we mean that the price on the next sale of a financial asset transaction to be executed will not differ by very much from the price of the previous transaction. As Peter L. Bernstein, author of the bestseller Against The Gods, has noted the existence of orderly financial markets for liquid assets encourage each holder (investor) of these securities to believe they can execute a fast exit strategy at any moment when they suddenly decide they are dissatisfied with the way things are happening without liquidity for these stocks, the risks of being a minority stock holder (owner) in a business enterprise would be intolerable. Nevertheless the liquidity of orderly equity markets and it's promotion of fast exit strategies makes the separation of ownership and control (management) of business enterprises an important economic problem that economists and politicians have puzzled over since the 1930s. In fact, Greenspan's surprise that the managers of large investment bankers were not protecting the interests of the owners of these corporations indicates he does not understand the difference liquid markets make in driving a wedge between ownership and control. In classical theory there can never be a separation in the decision making between owners and managers.

In my paper "Securitization, liquidity and market failure" (Davidson, 2008b) 
I explain why, as long as the future is uncertain and not just probabilistically risky, the price that liquid assets can sell for at any future date in a free market could vary dramatically and almost instantaneously. In the worse case scenario liquid financial assets could become unsaleable (illiquid) at any price as the market collapses (fails) in a disorderly manner creating toxic assets. This is what happened in the mortgage backed securities (MBS) markets.

To assure holders of liquid securities that the market price for their holdings will always change in an orderly manner, there must exist a person or firm in the market called a "market maker". The existence of this market maker assures the public that if, at any time, most holders of the financial asset suddenly want to execute a fast exit strategy and sell, while few or no people want to buy this liquid asset, the market maker has the obligation to enter the market and purchase a sufficient volume of the asset being offered for sale to assure that the new market price of the asset will change continuously in an "orderly" manner from the price of the last transaction. In essence the market maker assures the holders of a liquid asset that they can always execute a fast exit strategy at a price not much different than the last price. In the New York Stock Exchange these market makers are called "specialists".

Orderliness is a necessary condition to convince holders of the traded asset that they can readily liquidate their position at a market price close to the last publically announced price. In other words, orderliness is necessary to maintain liquidity in these markets. Orderliness provides preventive medicine against toxic assets.

Modern financial efficient market theory suggests that these quaint institutional arrangements for market maker specialists to create orderliness are antiquated in this computer age. With the computer and the internet, it is implied that the meeting of huge numbers of buyers and sellers can be done rapidly and efficiently in virtual space. Consequently there is no need for humans to act as specialists who keep the books and also make the market when necessary to assure the public the market is well organized and orderly. The computer can keep the book on buy and sell orders, matching them in an orderly manner, more rapidly and more cheaply than the humans who had done these things in the past.

In the many financial markets that failed in the Winter of 2007-2008 (e.g., the markets for mortgage backed assets, auction rate securities, et cetera), the underlying financial instruments that were to provide the future cash flow for investors typically were long term debt instruments. A necessary condition for these markets to be efficient is that the probabilistic risk of the debtors to fail to meet all future cash flow contractual debt obligations can be "known" with actuarial certainty. With this actuarial knowledge, it can be profitable for insurance companies to provide holders of these financial assets with insurance guaranteeing solvency and the payment of interest and principal liabilities by the debtors.

In the classical efficient market theory, any observed market price variation around the actuarial value (price) determined by fundamentals is presumed to be statistical "white noise". Any statistician will tell you, if the size of the sample increases, then the variance (i.e., the quantitative measure of the white noise) de- 
creases. Since computers can bring together many more buyers and sellers globally than the antiquated pre computer market arrangements, the size of the sample of trading participants in the computer age will rise dramatically. If, therefore, you believe in efficient market theory, then permitting computers to organize the market will decease significantly the variance and therefore increase the probability of a more well organized and orderly market than existed in the pre-computer era.

In a world of efficient financial markets, holders of market traded assets can readily liquidate their position at a price close to the previously announced market price whenever any holder wishes to reduce his/her position in that asset. If the efficient market theory is applicable to our world, then how can we explain so many securitized financial markets failing in the sense that investors are finding themselves locked into investments they can't cash out of?

Keynes's Liquidity theory can provide the explanation. Keynes presumes that the economic future is uncertain. If future outcomes can not be reliably predicted on the basis of existing past and present data, then there is no actuarial basis for insurance companies to provide holders of these assets protection against unfavorable outcomes. Accordingly, it should not be surprising that insurance companies such as AIG that have written policies to protect asset holders against possible unfavorable outcomes resulting from assets traded in these failing securitized markets find they have experienced billions of dollars more in losses than the companies had previously estimated (Morgenson, 2008). In a nonergodic world, it is impossible to actuarially estimate insurance payouts in the future.

Although the existence of a market maker provides, all other things being equal, a higher degree of liquidity for the traded assets, this assurance could dry up in severe sell conditions unless the Monetary Authority is willing to take direct action to provide resources to the market maker or, even indirectly to the market. If the market maker runs down his/her own resources and is not backed by the Monetary Authority indirectly, the asset becomes temporarily illiquid. Nevertheless, the asset holder "knows" that the market maker is providing his/her best effort to search to bolster the buyers' side and thereby restore liquidity to the market.

In markets without a market maker, on the other hand, there can be no assurance that the apparent liquidity of an assets can not disappear almost instantaneously. Moreover, in the absence of a market maker, there is nothing to inspire confidence that someone is working to try to restore liquidity to the market. Systemic market failure occurs when there is securitization and a well organized market exists without a market maker to assure orderliness.

Those who suggest that one only needs a computer-based organization of a market are assuming the computer will always search and find enough participants to buy the security whenever there is a large number of holders who want to sell. After all, the "white noise" of buyers and sellers at prices other than the equilibrium price in efficient markets is assumed to be normally distributed. Hence, by assumption, there can never be a shortage of participants on one side or the other of financial markets.

With the failure of thousands of security markets in the first weeks of 2008, it 
should be obvious that the computers failed to find sufficient buyers. Moreover the computer is not programmed to automatically enter into failing markets and begin purchasing when almost everyone wants to sell at, or near, the last market price. The investment bankers who organized and sponsor the many mortgage backed security markets will not act as market makers. These bankers may engage in "price talk" before the market opens ${ }^{1}$ to suggest to their clients what the probable range of today's market clearing price is likely to be. These "price talk" financial institutions, however, do not put their money where their mouth is. They are not required to try to make the market if the market clearing price is significantly below their "price talk" estimate.

Nevertheless there are many reports that representatives of these investment bankers have told clients that the holding of these assets "were 'cash equivalents" (Kim \& Amand, 2008). Many holders of these securities believed their holdings were very liquid since big financial institutions such as Goldman Sachs, Lehman Brothers, Merrill Lynch, etc. were the dealers who organized the markets and normally provided "price talk". In an article in the 2/15/2008 issue of the New York Times it was reported: "Some well-heeled investors got a big jolt from Goldman Sachs this week; Goldman, the most celebrated bank on Wall Street, refused to let them withdraw money from investments that they considered as safe as cash [...] Goldman, Lehman Brothers, Merrill Lynch, etc. have been telling investors the market for these securities is frozen - and so is their cash" (Anderson \& Bajaj, 2008, p. D4).

Obviously, participants in the market believed they were holding very liquid asset. Nevertheless, the absence of a credible market maker has shown these assets can easily become illiquid! Had these investors learned the harsh realities of Keynes's liquidity theory they might never participated in markets whose liquidity could be merely a fleeting mirage.

\section{POLICY IMPLICATIONS}

The policy response to the financial market failings we are experiencing can be broken into two parts. First, what can be done to prevent future reoccurrences of this widespread failure of public financial markets? Secondly, what, if anything, can be done today to limit any depressing effects of the current credit crunch developing in these securitized financial markets?

The question of prevention is the easier of the two to answer.

According to the web page of the United States Securities and Exchange Commission (www.sec.gov) "the mission of the US Securities and Exchange

\footnotetext{
${ }^{1}$ Before the day's auction begins, the investment banker will typically provide "price talk" to their clients indicating a range of likely clearing rates for that auction. This range is based on a number of factors including the issuer's credit rating, the last clearance rate for this and similar issues, general macroeconomic conditions, etc.
} 
Commission is to protect investors, maintain fair, orderly, and efficient markets, and facilitate capital formation". The SEC web page then goes on to note that the Securities act of 1933 had two basic objectives: "require that investors receive financial and other significant information concerning securities being offered for public sales, and prohibit deceit, misrepresentations, and other frauds in the sale of securities".

The SEC regulations typically apply to public financial markets where the buyer and the seller of an asset do not ordinarily identify themselves to each other. In a public financial market each buyer purchases from the impersonal marketplace and each seller sells to the impersonal market. It is the responsibility of the SEC to assure investors that these public markets are orderly.

[In contrast, a private financial market would be where both the buyer and the seller of the any financial asset are identified to, and know, each other. For example, bank loans are typically a private market transaction that would not come under the purview of the SEC. In the past, there was no resale market for loan securities created in private financial markets. The issued asset from a transaction in a private market traditionally has been an illiquid asset that the lender "knew" he/she would have to keep the loan debt contract on the asset side of his/her balance sheet until the loan was paid off or the borrower went into default. Under such conditions, the lender knew enough to carefully check the borrower for the three C's - Collateral, Credit History, and Character - before granting a loan.]

On its web page, The Securities and Exchange Commission also declares that: "As more and more first-time investors turn to the markets to help secure their futures, pay for homes, and send children to college, our investor protection mission is more compelling than ever". Given the current experience of contagious failed and failing public financial markets, it would appear that the SEC has been lax in pursuing its stated mission of investor protection. Accordingly the United States Congress should require the SEC to enforce diligently the following rules:

1. Public notice of potential illiquidity for public markets that do not have a credible market maker. In the last quarter of a century, large financial underwriters have created public markets, which, via securitization, appeared to convert long term debt instruments (some of them very illiquid, e.g., mortgages) into the virtual equivalent of high yield, very liquid money market funds and other short term deposit accounts. As the newspaper reports that we have cited indicate, given the celebrated status of the investment bank-underwriters of these securities and the statements of their representatives to clients, individual investors were led to believe that they could liquidate their position at an orderly change in price from the publically announced clearing price of the last public auction.

This perceived high degree of liquidity for these assets has now proven to be illusionary. Purchasers might have recognized the potential low degree of liquidity associated with these assets if the buyers were informed of all the small print regarding market organization. In markets such as the auction rate security markets, for example, although the organizer-underwriter could buy for their own account, they were not obligated to maintain an orderly market. Since the mandate of the SEC is 
to assure orderly public financial markets, and "require that investors receive financial and other significant information concerning securities being offered for public sales, and prohibit deceit, misrepresentations, [...] in the sale of securities”, it is would seem obvious that all public financial markets that are organized without the existence of a credible market maker should, either (1) be shut down because of the potential for disorderliness, or (2) at a minimum, information regarding the potential illiquidity of such assets should be widely advertised and made part of essential information that must be given to each purchaser of the asset being traded.

The draconian action suggested in (1) above is likely to meet with severe political resistence, as the financial community will argue that in a global economy with the ease of electronic transfer of funds, a prohibition of this sort would merely encourage investors looking for higher yields to deal with foreign financial markets and underwriters to the detriment of domestic financial institutions and domestic industries trying to obtain capital funding.

Elsewhere, I have proposed (Davidson, 2007) an innovative international payments system ${ }^{2}$ that could prevent US residents from trading in foreign financial markets that the US deemed detrimental to American firms that obeyed SEC rules while foreign firms did not follow SEC rules. If, however, we assume that the current global payments system remains in effect, and there is a fear of loss of jobs and profits for American firms in the FIRE industries, then the SEC could permit the existence of public financial markets without a credible market maker as long as the SEC required the organizers of such markets to clearly advertise the possible loss of liquidity that can occur to holders of assets traded in these markets.

A civilized society does not believe in "caveat emptor" for markets where products are sold that can have terribly adverse health effects on the purchaser. Despite the widespread public information that smoking is a tremendous health hazard, government regulations still require cigarette companies to print in bold letters on each package of cigarettes the caution warning that "Smoking can be injurious to your health". In a similar manner, any purchases on an organized public financial market that does not have a credible market maker can have serious financial health effects on the purchasers. Accordingly, the SEC should require the following warning to potential purchasers of assets traded in a market without a credible market maker: "This market is not organized by a SEC certified credible market maker. Consequently it may not be possible to sustain the liquidity of the assets being traded. Holders must recognize that they may find that their position in these markets can be frozen and they may be unable to liquidate their holdings for cash."

Furthermore, the SEC should set up strictly enforced rules regarding the minimal amount of financial resources relative to the size of the relevant market that an entity must possess in order to be certified as a credible market maker. The SEC will be required to re-certify all market makers periodically, but at least once a year.

\footnotetext{
${ }^{2}$ My proposed international payments system is a variant of the Keynes Plan that was presented by Keynes at the Bretton Woods conference in 1944 and rejected by the United States.
} 
2. Prohibition against securitization that attempts to create a public market for assets that originated in private markets. The SEC should prohibit any attempt to create a securitized market for any financial instrument or a derivative backed by financial instruments that originates in a private financial market (e.g., mortgages, commercial bank loans, etc.).

3. Congress should legislate a $21^{\text {st }}$ century version of the Glass Steagall Act. The purpose of such an act should force financial institutions to be either an ordinary bank lender creating loans for individual customers in a private financial market, or an underwriter broker who can only deal with instruments created and resold in a public financial market.

What can be done to mitigate the depressing consequences of the current financial mess?

In two earlier papers (Davidson, 2008a, 2008b), I proposed the creation of a $21^{\text {st }}$ century equivalents of the Roosevelt era Home Owners Loan Association (HOLC), and the Bush I Administration's Resolution Trust Company (RTC) to alleviate the United States housing bubble crisis and to prevent potential massive insolvency problems by removing toxic assets from financial institutions' balance sheets while penalizing managers and stockholders of these financial institutions.

\section{REFERENCES}

ANDERSON, Jenny \& BAJAJ, Vikas (2008) “New trouble in auction-rate securities”, New York Times, February 15, p. D4.

CRESWELL, Julie \& BAJAJ, Vikas (2008) “Municipalities feel pinch as another debt market falters", New York Times, February 15, p. D1.

DAVIDSON, P. (1982-1983) "Rational expectations: a fallacious foundation for studying crucial decision making processes", Journal of Post Keynesian Economics, 5, Winter reprinted in Inflation, Open Economies and Resources, The Collected Writings of Paul Davidson, vol. 2, (1991) New York: New York University Press, pp. 123-143. London and New York: Palgrave/Macmillan, 2007.

DAVIDSON, P. (2008a) "How to solve the U.S. housing problem and avoid recession: A revived HOLC and RTC", Schwartz Center for Economic Policy Analysis: Policy Note, January 2008, online at: www.newschool.edu/cepa or http//eco.bus.utk.edu/davidson.html.

DAVIDSON, P. (2008b) "Securitization, liquidity and market failure”, Challenge, 51, May/June.

DAVISON, P. (2009) The Keynes Solution. New York: Palgrave.

KEYNES, J. M. (1936) The General Theory of Employment Interest and Money. New York: Harcourt.

KIM, Jane J. \& ANAND, Shefali (2008) “Some Investors forced to hold 'auction' bonds: market freeze leaves them unable to cash out securities that were pitched as 'safe"', Wall Street Journal February 21, p. D1.

MORGENSON, Gretchen, (2008)“Arcane market is next to face big credit test”, New York Times, February 17, p. A1.

RAGHAVAN, Anita, PULLIAM, Susan \& OPDYKE, Jeff, (2001) "Team effort: banks and regulators drew together to calm markets after attack", Wall Street Journal, October 18, p. A1.

SAMUELSON, P. A. (1969) "Classical and Neoclassical Theory" in CLOWER, R.W., ed. Monetary Theory. London: Penguin. 